\title{
MODELING THE MOVEMENT OF A MISSILE IN THE TUBULAR GUIDE OF THE STARTING INSTALLATION
}

\author{
Oleksandr M. Shyiko ${ }^{\mathrm{a}}$, Anatoly M. Pavlyuchenko ${ }^{\mathrm{b}}$, \\ Olexii A. Obukhov ${ }^{\mathrm{c}}$, Igor V. Koplyk ${ }^{\mathrm{d}}$ \\ ${ }^{a}$ National Agricultural University, Sumy, Ukraine, corresponding author, \\ e-mail: shyikoa@ukr.net, \\ ORCID iD: Dhttp://orcid.org/0000-0002-4297-911X \\ ${ }^{\mathrm{b}}$ National Agricultural University, Sumy, Ukraine, \\ e-mail: apavlucenko22@gmail.com, \\ ORCID iD: (iDhttps://orcid.org/0000-0003-0827-2847 \\ ${ }^{\mathrm{c}}$ Research Center of Rocket Forces and Artillery, Sumy, Ukraine, \\ e-mail: obukhov.olexii@gmail.com, \\ ORCID iD: (1) https://orcid.org/0000-0003-0846-2288 \\ ' State University, Sumy, Ukraine, \\ e-mail: igor.kopl@gmail.com, \\ ORCID iD: (Dhttps://orcid.org/0000-0003-2217-731X
}

DOI: 10.5937/vojtehg67-22681; https://doi.org/10.5937/vojtehg67-22681

\begin{abstract}
FIELD: Mechanics, Artillery and Rocket Weapons ARTICLE TYPE: Original scientific paper ARTICLE LANGUAGE: English
\end{abstract}

\section{Summary:}

The paper presents computational and mathematical model of the spatial motion of a rocket with centering bulges and a pin on the body in a thinwalled tubular guide mounted on two fixed supports and equipped with a screw groove. The models take into account the interaction of the projectile with the inner surface of the guide tube at the locations of the drive pin and the centering bulge. The strength of the normal reaction of the inner surface of the guide is found as a reaction to the elastic deformation of the pipe caused by normal to its inner surface displacements of the centering thickening at the point of contact with the guide. In this case, the tubular guide is considered as an elastic thinwalled shell. To calculate the values of the shell stiffness coefficient along its length, the finite element method implemented in the ANSYS Mechanical software package is used. The translational component of the projectile motion is investigated on the basis of the theorem on the motion of the center of mass. The rotational component is investigated on the basis of the Lagrange equations of the second kind. The generalized parameters of the rotational motion are the yaw $\psi$ and pitch $\theta$ angles, the angle of attack $\alpha$, the angle of slip $\beta$, and the angle of rotation of the projectile around the longitudinal axis $\varphi$. The aerodynamic angle of heel $\mathrm{Ya}_{\mathrm{a}}$ is found from the transition formulas for the adopted coordinate systems. 
The yaw velocity angle $\Psi$, the pitch velocity angle $\theta$, and the aerodynamic roll angle $\mathrm{y}_{a}$ as well as the first time derivatives of these angles are converted into the yaw angles $\psi$ and pitch $u$ of the projectile axis and their derivatives in the starting coordinate system.

Keywords: missile launcher, movable launcher, elastic model, launching tube, spatial portion of movement, interaction forces, angles of vectors, center of mass velocities, projectile axis angles.

\section{Introduction}

The creation of computational and mathematical models of the movement of a missile in a launcher tubular guide (Fig. 1) precedes a physical model. In most works, the projectile is considered to be a smooth solid, which, when moving in a guide, tracks the angular movements of the chassis and package of guides (Svetlickij, 1986), (Somoiag et al, 2007, pp.95-97), (Antunevich et al, 2017, pp.207-208), (Dziopa et al, 2010, pp.645-646), (Dziopa et al, 2015, pp.71-72). In fact, the physical model of the movement of the projectile inside the tubular guide is much more complicated. While moving, the projectile body rests on the inner surface of the guide pipe centering thickenings. After the penultimate centering, the bulge extends beyond the muzzle cut, the projectile moves into the guide tube, resting on the inner surface of the tube with the leading edge of the last centering bulge. The formation of absolute angles of departure and angular velocities of departure due to the relative rotation of the guide in the pipe and the movement of the pipe itself during the flight in the pipe and their determination for the moment of the descent of the missile from the launch guide constitute the essence and the problem of angular initial disturbances of the missile trajectories.

To solve the mission of a missile at launch from a launcher in design models of projectile motion in a launcher, the same parameters defining the position of the projectile should be used as in calculating the flight trajectory. Such parameters (Fig. 2) can be the coordinates and the velocity of the center of mass of the projectile, yaw velocity angles $\Psi$, pitch $\theta$, determining the direction of the velocity vector of the center of mass, the angle of attack $\alpha$ and the slip $\beta$, determining the position of the axis of the projectile relative to the velocity vector of the center of mass, the aerodynamic angle $\gamma_{a}$ roll, the yaw angles $\psi$ and the pitch $u$ of the projectile axis (Svetlickij, 1986), (Raducanu et al, 2009, pp.1459-1460). 


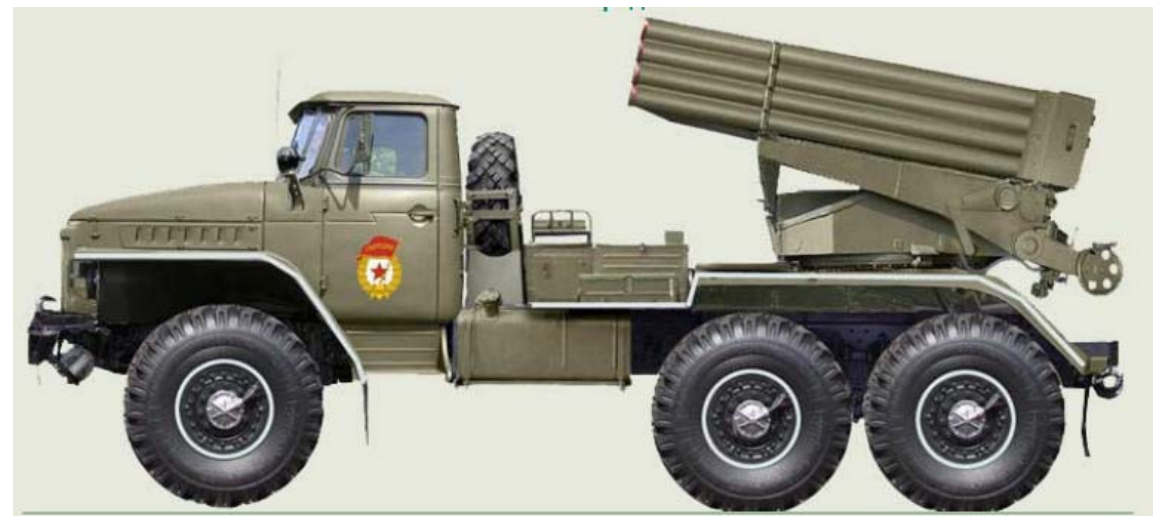

Figure 1 - Mobile launcher RSZO BM-21

Puc. 1 - Мобильная пусковая установка РСЗО БМ-21

Слика 1 - Самоходни вишецевни бацач ракета РСЗО БМ-21

In modern designs of launchers, for giving the projectile rotation, the tubular guide is provided with a screw groove, and a leading pin is placed on the body of the projectile. The disadvantage of the above and many other design models is that they do not take into account the impact on the movement of the projectile and the launcher interaction of the projectile and the guide launcher in a pair of pin-groove.

When determining the estimated area of dispersion of a series of missiles launched from a mobile launcher, it is necessary to determine, for each calculated elevation angle of the guideline, a reference or a baseline trajectory obtained by simulating the launch of the projectile from the central position of the guide package with its static equilibrium and no fluctuations of the launcher. This condition leads to a computational model of launching a projectile from a single tubular guide rigidly connected to the base. Such a model can also be used to determine calculated tabular corrections for changes in the ballistic and meteorological conditions of the launch.

Unlike traditional methods for calculating the interaction force between a projectile and a tubular guide using differentiated coupling equations (Svetlickij, 1986), (Somoiag et al, 2007, pp.95-97), (Shyiko, 2014, pp.47-51), the normal reaction force of the inner surface of a guide pipe can be viewed as a reaction to the elastic deformation of the pipe caused by projectile support points normal to the inner surface of the pipe. at the point of contact with the guide (Bogomolov, 2003, pp.207208). Such a computational model of the dynamic response of the tubular guide allows us to directly associate the resulting reaction with the 
translational and rotational components of the displacement of the projectile relative to the guide tube, which greatly simplifies the calculation of this force in the numerical integration of the equations of motion.

\section{Purpose of the research}

The purpose of the research was to develop computational and mathematical model of the spatial motion of a rocket with centering piles and a leading pin on the body in an elastic thin-walled tubular guide fixed on rigidly fixed base supports and equipped with a screw groove that take into account the interaction of the projectile with the inner surface of the guide rail at the locations of the leading pin and centering projectile thickening. The aim was also to calculate the values of angles and angular velocities of the projectile when departing from the guide, using the characteristics of the elastic properties of the guide.

\section{Presentation of the main material}

We consider the movement of a jet projectile with centering bulges in a pliable elastic tubular guide which has an inclined helical groove for the driving pin on the projectile body, and we obtain the differential equations of the projectile motion after the exit of the penultimate centering bulge from the guide tube. To do this, we introduce the necessary coordinate systems and angles that determine their mutual positions (Fig. 2):

- an immovable coordinate system $C^{\prime} x_{\Pi} y_{\Pi} z_{\Pi}$ permanently connected with the guide, the origin of which is in the initial position of the projectile center of mass, and the axis $\mathrm{x} \Pi$ of which coincides with the longitudinal axis of the guide tube - the launch coordinate system,

- a fixed coordinate system $C^{\prime} x y z$, the origin of which is in the initial position of the projectile center of mass - the starting coordinate system,

- the trajectory coordinate system CTNB with the beginning in the projectile center of mass, the axis $T$ of which coincides with the velocity vector of the center of mass,

- the velocity coordinate system $\mathrm{Cx}_{a} \mathrm{y}_{\mathrm{a}} \mathrm{z}_{\mathrm{a}}$ with the origin at the center of mass, the ya axis of which coincides with the velocity vector of the center of mass, and

- the semi-connected coordinate system $C \zeta \xi \eta$, which is always connected with the projectile, does not participate in the projectile rotation around the longitudinal axis and the beginning of which is in the 
projectile center of mass, and the axis $\zeta$ coincides with the projectile longitudinal axis.

The forces acting on the projectile (Fig. 2) are: the reactive force $\overrightarrow{\mathrm{P}}(\mathrm{t})$, the force of gravity $\overrightarrow{\mathrm{mg}}$, the normal reaction $\overrightarrow{\mathrm{R}}$ of the pipe surface at the reference point "A", the friction force $\vec{F}_{T}$ at the reference point associated with the movement of the projectile along the guide and equal to $f \cdot R$, where $f$ is the coefficient of friction between the surface of the projectile and the surface of the tubular guide, the normal reaction of the screw groove $\overrightarrow{\mathrm{N}}(\mathrm{t})$, and the friction force between the drive pin and the side surface of the screw groove, equal to $\mu \cdot \mathrm{N}$, where $\mu$ is the coefficient of friction between the drive pin and the side surface of the screw groove. Since the projectile has a forced rotation by means of a screw groove and a pin, the circumferential tangential friction force $\vec{F}_{T l}$ between the body of the projectile and the guide is added to the acting forces.

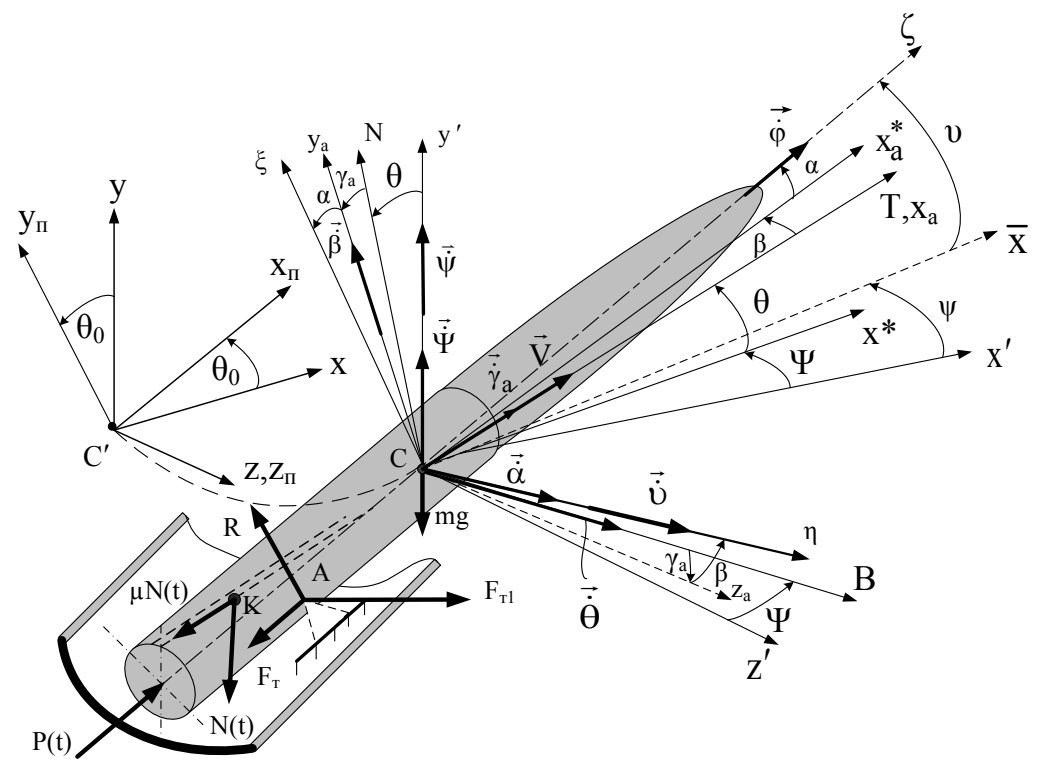

Figure 2 - Coordinate systems and angles that determine their mutual positions on the site of the spatial movement of the projectile in a tubular guide

Puc. 2 - Системы координат и углы, определяющие их взаимное положение на участке пространственного движения снаряда в трубчатой направляющей Слика 2 - Координатни системи и углови који одређују њихов међусобни положај на месту просторног кретања пројектила у лансирној цеви 
The tubular guide is a thin-walled structure that provides the necessary rigidity and strength with a relatively light weight. From the standpoint of continuum mechanics, the guide can be considered as a thin-walled shell placed on supports elastic with respect to transverse displacements, rigidly attached to the base and loaded from the inside by sliding pressure forces of the projectile support belts (Bogomolov, 2003, pp.207-208). When calculating the deflections of such a shell from the action of the radial force applied from the inside of the shell at different points forming the inner surface of the shell, we find the values of the coefficient of radial stiffness of the tubular guide along its length.

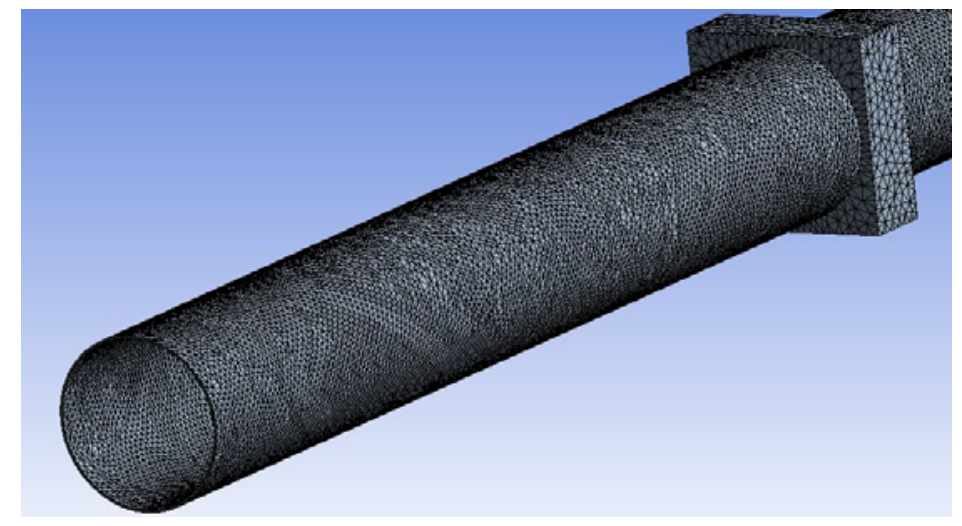

Figure 3 - Finite-element model of a tubular guide, modeled by the ANSYS finiteelement analysis software package

Puc. 3 - Конечно-элементная модель трубчатой направляющей, смоделированная программным пакетом конечно-элементного анализа ANSYS Слика 3 - Модел коначних елемената лансирне цеви, моделован помоћу ANSYS софртверског пакета са коначним елементима

To calculate the values of the stiffness coefficient in this work, we used the ANSYS Mechanical software product which analyzes the stress-strain state of the shell structure in which it is performed in a finite element analysis package. The finite element model of the guide, which includes the pipe and fragments of the bearing diaphragms of the guide package, is shown in Fig. 3.

Fig. 4 shows the result of a further approximation of the calculated tabulated deflection function $\delta$ from the action of the radial force $P=647$ $\mathrm{N}$ at the point of application of force with the aim of smoothing it by a 7th degree polynomial by the least squares method. The coefficient $C$ of the radial stiffness of the tubular guide at the point of force application is determined by dividing the magnitude of the applied force by the value of 
the radial displacement of the inner surface of the pipe at the point of application of force.

$$
\delta, \mathrm{mm}
$$

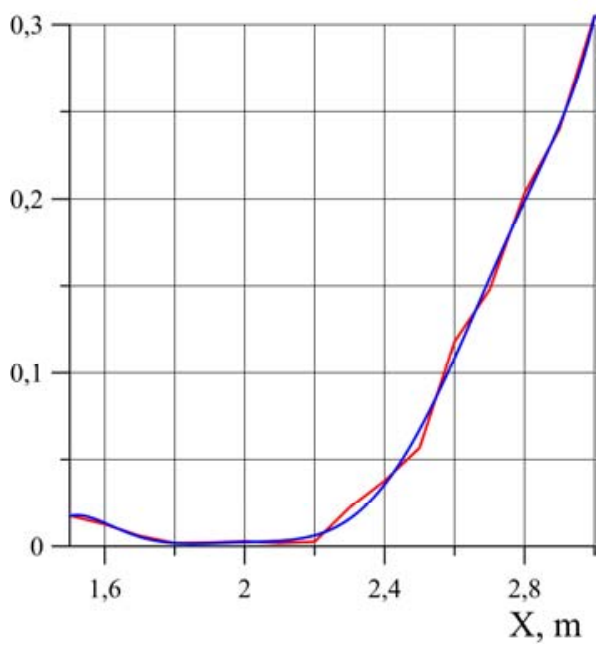

Figure 4 - Approximation of the results of calculating the values of radial elastic displacements $\delta$ from the action of the radial force $P=647 \mathrm{~N}$ in the place of application of the force by a polynomial of the 7 th degree

Puс. 4 - Аппроксимация результатов расчета значений радиальных упругих перемещений $\delta$ от действия радиальной силы $P=647 \mathrm{H}$ в месте приложения силы полиномом 7-ой степени

Слика 4 - Приближни резултати прорачуна вредности радијалних еластичних помака $\delta$ од дејства радијалне силе $P=647 \mathrm{H}$ на месту примене силе полиномом

$$
\text { 7. степена }
$$

The projection, magnitude and direction of the vector $\vec{\rho}$ (Fig. 5) of the radial displacement of the axis of the projectile relative to the axis of the pipe in the plane of the cross section of the pipe containing the point " $A$ " of the contact of the projectile with the pipe, on the axis of the launch system $C^{\prime} x_{\Pi} y_{\Pi} z_{\Pi}$, the axis of which $x_{n}$ coincides with the longitudinal axis of the projectile, are defined using the generalized coordinates of the shell as follows:

$$
\begin{aligned}
& \rho_{y}=y_{n}-v_{n} \cdot L_{n} ; \rho_{z}=z_{n}+\psi_{n} \cdot L_{n} ; \\
& \rho=\sqrt{\rho_{y}^{2}+\rho_{z}^{2}} ; \quad \operatorname{tg} \lambda=\rho_{z} /\left(-\rho_{y}\right)
\end{aligned}
$$

where $\mathrm{y}_{\Pi}, \mathrm{z}_{\Pi}$ are the coordinates of the center of mass of the projectile in the launch coordinate system $C^{\prime} x_{\Pi} y_{\Pi} z_{\Pi} ; L_{\Pi}$ is the distance from the 
center of mass to the beginning of the last centering thickening; and $\psi_{\Pi}, v_{\Pi}$ are the angles that determine the position of the axis of the projectile relative to the axes of the launch system $C^{\prime} x_{\Pi} y_{\Pi} z_{\Pi}$. The value of the elastic reaction:

$$
R=C \cdot \delta, \quad \delta=\rho-\Delta \geq 0,
$$

where $\delta$ is the value of the elastic deformation of the guide tube at the point of contact of the centering thickening with the pipe, and $\Delta$ is the value of the technological radial clearance between the centering thickening on the projectile shell and the inner surface of the guide tube.

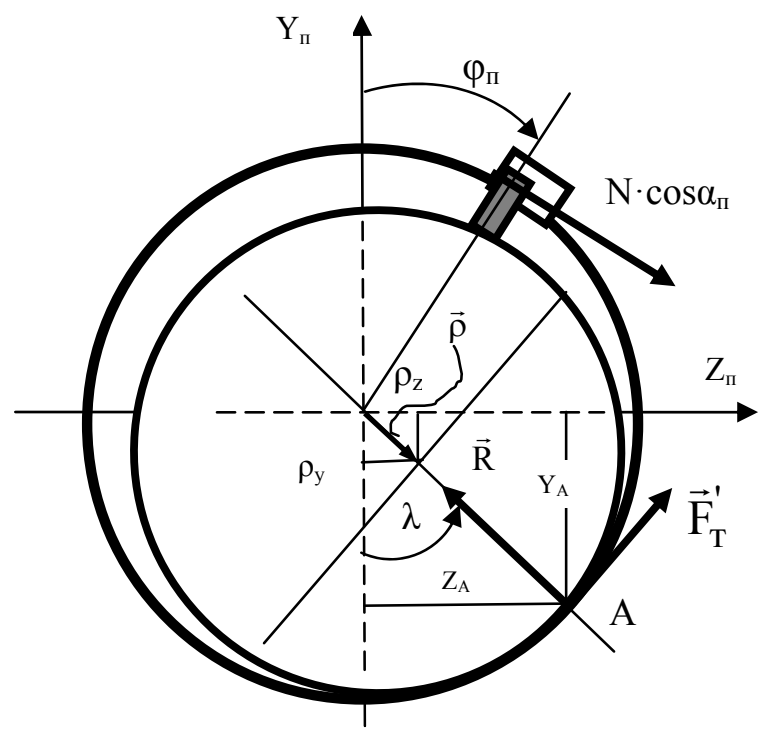

Figure 5 - Elastic response of the tubular guide to the pressure of the centering protrusion of the projectile

Puc. 5 - Упругая реакция трубчатой направляющей на давление центрирующего пояска снаряда

Слика 5 - Еластична реакција лансирне цеви на притисак центрирајућег појаса пројектила

The projections of the elastic reaction of the guide tube $\vec{R}$ on the axis of the launch coordinate system $C^{\prime} x_{\Pi} y_{\Pi} z_{\Pi}$ are respectively equal to:

$$
R_{x}=0 ; \quad R_{y}=-R \cdot \rho_{y} / \rho ; \quad R_{z}=-R \cdot \rho_{z} / \rho
$$


Fig.6 presents the calculated values of the elastic reaction $R$ of the guide at the contact point along the length of the spatial motion section of the M-21OF type missile inside the tubular guide with a helical groove like the guide of the BM-21 mobile launcher at various elevation angles $\theta_{0}$ of the tube guide. The estimated wall thickness of the guide tube is $\mathrm{h}=2.0 \mathrm{~mm}$. The guide length is adopted to be $\mathrm{L}=3.0 \mathrm{~m}$. Fig. 7 shows the calculated change in the force $R$ in the initial portion of the spatial motion of the projectile in the pipe.

It can be seen that, regardless of the specified initial elastic deformation of the guide tube, the force $\mathrm{R}$ converges quickly enough to a single calculated dependence. The length of the installation area is about $3 \mathrm{~mm}$. Short-term calculated fluctuations in the elastic deformation of the pipe and the force $R$ in the end do not affect the nature of the calculated dependences for the quantities characterizing the projectile movement.

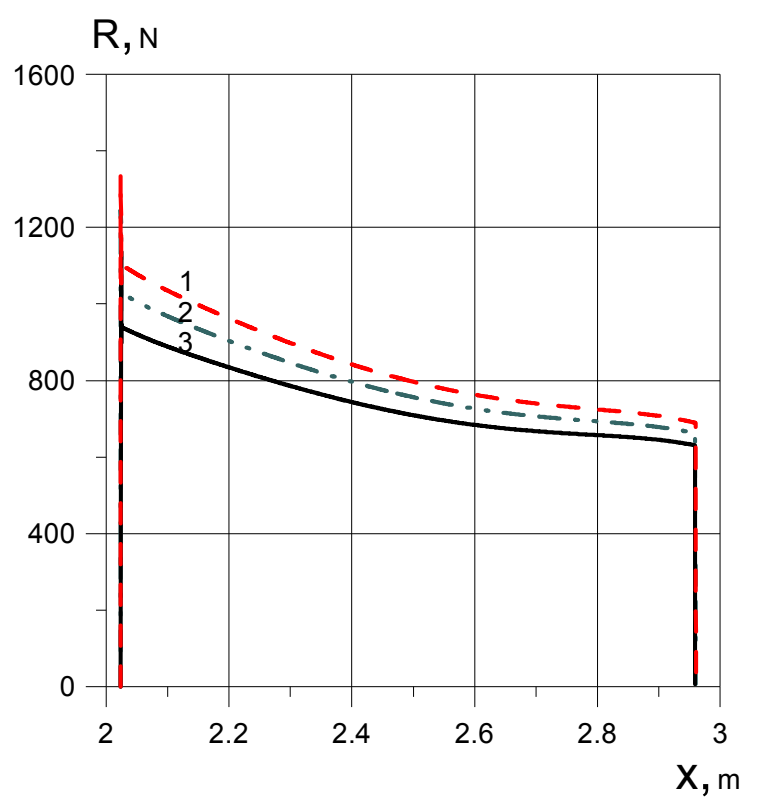

Figure 6 - Calculated values of the reaction $R$ of the guide at the point of contact along the length of the section $x$ of the spatial movement of the projectile at different elevation angles $\theta_{0}$ of the tubular guide: $1-\theta_{0}=19^{\circ} 4^{\prime} ; 2-\theta_{0}=33^{0} 3 ; 3-\theta_{0}=45^{\circ} 46^{\prime}$.

Puc. 6 - Расчетные значения реакции $R$ направляющей в точке контакта по длине участка х пространственного движения снаряда при различных углах $\theta_{0}$ возвышения трубчатой направляющей: $1-\theta_{0}=19^{\circ} 4^{\prime} ; 2-\theta_{0}=33^{\circ} 36 ; 3-\theta_{0}=45^{\circ} 46^{\prime}$. Слика 6 - Израчунате вредности реакције $P$ лансирне цеви у тачки контакта дуж сегмента х просторног кретања пројектила на различитим угловима елевације $\theta_{0}$ лансирне цеви: $1-\theta_{0}=19^{\circ} 4^{\prime} ; 2-\theta_{0}=33^{\circ} 36 ; 3-\theta_{0}=45^{\circ} 46^{\prime}$. 


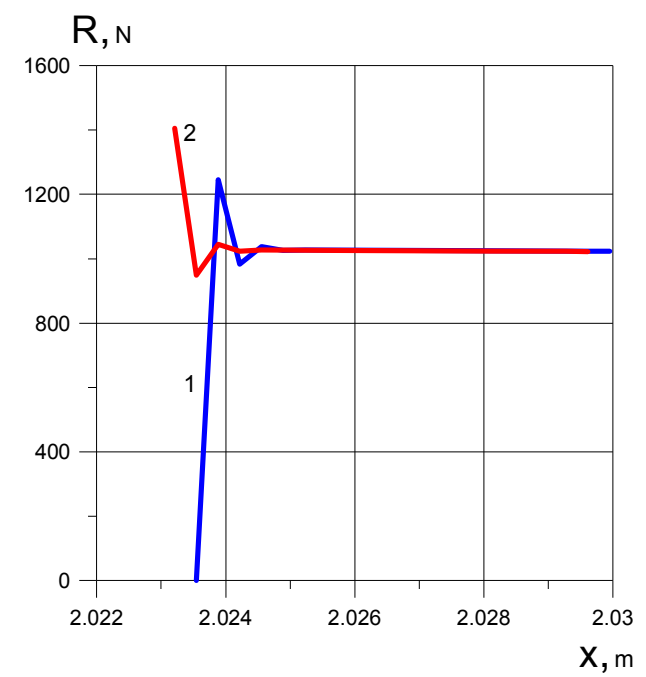

Figure 7 - Calculated reaction values $R$ of the guide along the length $x$ of the initial part of the spatial motion of the projectile at $\theta_{0}=33^{0} 36^{\prime}$ and different initial values of the deformation of the guide tube at the point of contact: 1 - no deformation; 2 - deformation on a force equal to the projectile weight.

Puc. 7 - Расчетные значения реакции $R$ направляющей по длине х начального участка пространственного движения снаряда при $\theta_{0}=33^{0} 36^{\prime}$ и различных начальных значениях деформации трубы направляющей в точке контакта: 1деформация отсутствует; 2- дефрормация от силы равной весу снаряда.

Слика 7 - Израчунате вредности реакције $P$ водишта дуж дужине х почетног дела просторног кретања пројектила на $\theta_{0}=33^{0} 36^{\prime}$ и различите почетне вредности деформације лансирне цеви у тачки додира: 1 - нема деформације; 2 дефрормација од силе која је једнака тежини пројектила.

The normal dynamic reaction force of the screw groove is found by the dependence (Bogomolov, 2003, pp.81-82):

$$
N(t)=k_{1} \cdot P(t)-k_{2} \cdot Q_{p}
$$

where $\mathrm{k}_{1}, \mathrm{k}_{2}$ are the coefficients depending on the angle of inclination of the screw groove $\alpha_{\Pi}$, the coefficient of friction $f$ of the projectile on the guide, the angle $\theta_{0}$ of inclination of the guide; projectile mass $\mathrm{m}_{\mathrm{p}}$; and moment of inertia I of the projectile relative to the longitudinal axis.

The total projections of the force $\overrightarrow{\mathrm{N}}(\mathrm{t})$ and the friction force of the screw groove on the axis of the launch coordinate system $C^{\prime} x_{\Pi} y_{\Pi} z_{\Pi}$ in the corresponding designations $\mathrm{Nx}, \mathrm{Ny}, \mathrm{Nz}$ are 


$$
\begin{gathered}
N_{x}(t)=-N(t) \cdot\left(\sin \alpha_{\Pi}+\mu \cdot \cos \alpha_{\Pi}\right) . \\
N_{y}(t)=-N(t) \cdot\left(\cos \alpha_{\Pi}-\mu \cdot \sin \alpha_{\Pi}\right) \cdot \sin \varphi_{n} . \\
N_{z}(t)=N(t) \cdot\left(\cos \alpha_{\Pi}-\mu \cdot \sin \alpha_{\Pi}\right) \cdot \cos \varphi_{n} .
\end{gathered}
$$

where $\varphi_{\Pi}$ is the angular coordinate of the groove (Fig. 5).

The differential equations of motion of the center of mass of the projectile in a fixed launch coordinate system $C^{\prime} x_{\Pi} y_{\Pi} z_{\Pi}$ and in the projections on the axis of the CTNB trajectory system are given at the end of the article together with the equations of rotational motion of the projectile relative to the center of mass in a single system of equations (14).

To compile the equations of the rotational motion of the projectile relative to the center of mass, we use the Lagrange equations of the 2 nd kind in the generalized coordinates:

$$
\frac{d}{d t}\left(\frac{\partial T}{\partial \dot{q}_{i}}\right)-\frac{\partial T}{\partial q_{i}}=Q_{i}
$$

The generalized coordinates of the rotational motion of the projectile relative to the center of mass in the coordinate system $C^{\prime} x^{\prime} y^{\prime} z^{\prime}$, which moves progressively with the center of mass of the projectile and whose axes are parallel to the axes of the starting system C'xyz, which has a start in the initial position of the center of mass of the projectile, are the angles $\Psi$ and $\theta$ which determine the direction of the tangent to the trajectory of the center of mass, the angles $\alpha$ and $\beta$ which determine the direction of the projectile axis with respect to the tangent, and the angle $\varphi$ of the projectile rotation around the longitudinal axis.

When considering the motion of a projectile with respect to its center of mass, we take into account only the kinetic energy of this movement, not taking into account the energy of translational motion. In this case:

$$
T=\frac{1}{2} \cdot\left(A \cdot p^{2}+B \cdot q^{2}+C \cdot r^{2}\right),
$$

where $A, B$ and $C$ are the moments of inertia of the projectile relative to the main central axes of inertia, which are the axes of the semiconnected system $\mathrm{C} \zeta \eta \zeta$, which does not take part in the rotation of the projectile around its longitudinal axis $\zeta$ (Fig. 2), p, q, and $r$ are the projections of the instantaneous angular velocity vector of the projectile on these axes. 

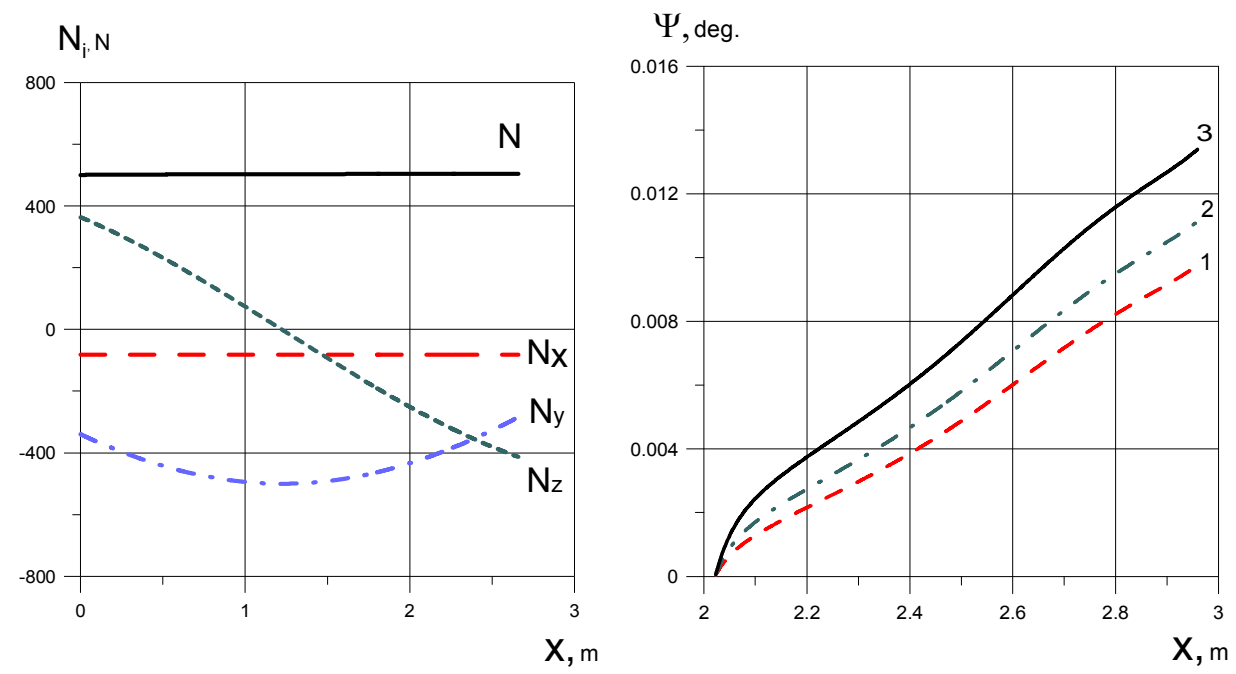

Figure $8-$ Calculated values of the reaction force of the screw groove $N$ and its projections on the axes of the starting coordinate system, as well as the yaw velocity angle $\psi$ along the length $x$ of the spatial movement of the projectile at different elevation angles $\theta_{0}$ of the tubular guide: $1-\theta_{0}=19^{\circ} 4^{\prime} ; 2-\theta_{0}=33^{\circ} 36^{\prime} ; 3-\theta_{0}=45^{\circ} 46^{\prime}$.

Puc. 8 - Расчетные значения силы реакции винтового паза $N$ и его проекций на оси пусковой системы координат, а также скоростного угла рыскания $\psi$ по длине участка х пространственного движения снаряда при различных углах $\theta_{0}$ возвышения трубчатой направляющей: $1-\theta_{0}=19^{\circ} 4^{\prime} ; 2-\theta_{0}=33^{0} 36^{\prime} ; 3-\theta_{0}=45^{\circ} 46^{\prime}$.

Слика 8 - Прорачунате вредности силе реакције спиралног вијка $N$ и њених пројекција на оси стартног координатног система, као и угао скретања брзине

$\Psi$ дуж сегмента х просторног кретања пројектила на различитим угловима елевације $\theta_{0}$ лансирне цеви: $1-\theta_{0}=19^{\circ} 4^{\prime} ; 2-\theta_{0}=33^{0} 36^{\prime} ; 3-\theta_{0}=45^{\circ} 46^{\prime}$.

The components of the angular velocity of the projectile will be considered as the angular velocity associated with the rotation of the axis of the projectile and its own rotation. We obtain the instantaneous angular velocity of the projectile by sequentially adding the angular velocities of the trajectory system relative to the starting $(\overrightarrow{\dot{\Psi}}+\overrightarrow{\dot{\theta}})$, the velocity system relative to the half-connected system $(\overrightarrow{\dot{\alpha}}+\overrightarrow{\dot{\beta}})$, and the angular velocity of its own rotation $\overrightarrow{\dot{\varphi}}$ (Fig. 2). In this way:

$$
\vec{\Omega}=\overrightarrow{\dot{\Psi}}+\overrightarrow{\dot{\theta}}+\overrightarrow{\dot{\alpha}}+\overrightarrow{\dot{\beta}}+\overrightarrow{\dot{\varphi}}
$$



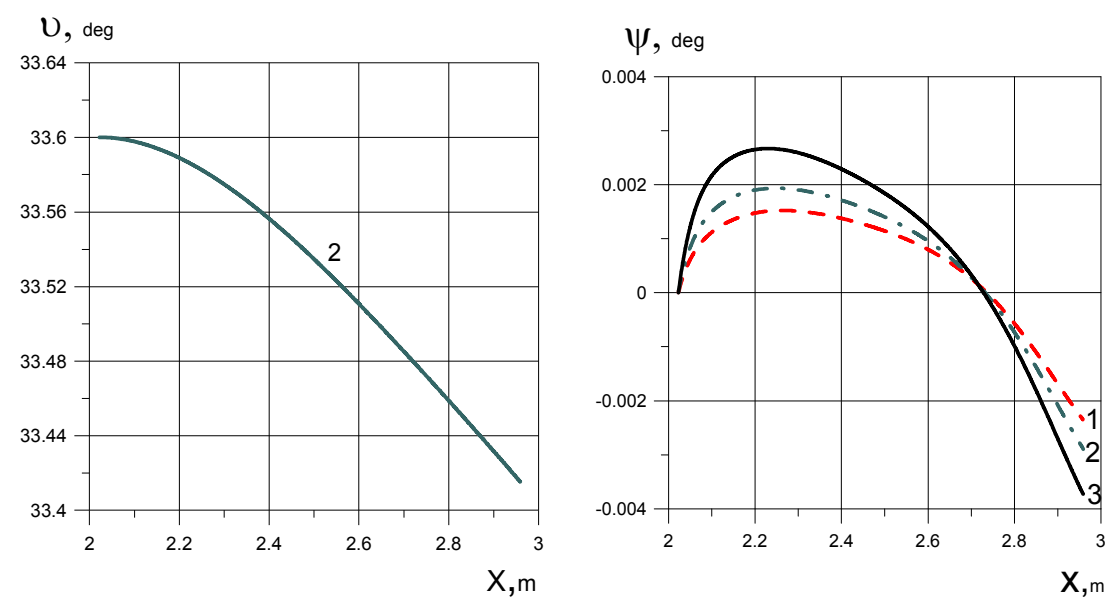

Figure 9 - Calculated values of the pitch angle $u$ and the yaw angle $\psi$ of the axis of the projectile along the length $x$ of the spatial movement at different elevation angles $\theta_{0}$ of the tubular guide: $1-\theta_{0}=19^{\circ} 4^{\prime} ; 2-\theta_{0}=33^{\circ} 36^{\prime} ; 3-\theta_{0}=45^{\circ} 46^{\prime}$.

Puc. 9 - Расчетные значения угла тангажа $v$ и угла рыскания $\psi$ оси снаряда по длине участка х пространственного движения при различных углах $\theta_{0}$ возвышения трубчатой направляющей: $1-\theta_{0}=19^{\circ} 4^{\prime} ; 2-\theta_{0}=33^{\circ} 36^{\prime} ; 3-\theta_{0}=45^{\circ} 46^{\prime}$.

Слика 9 - Израчунате вредности угла нагиба $v$ и угла $\psi$ скретања осовине пројектила дуж дужине х просторног кретања на различитим угловима елевације $\theta_{0}$ лансирне цеви: $1-\theta_{0}=19^{\circ} 4^{\prime} ; 2-\theta_{0}=33^{\circ} 36^{\prime} ; 3-\theta_{0}=45^{\circ} 46^{\prime}$.

Summing up the projections of the components of the angular velocity, we will get:

$$
\begin{gathered}
p=\Omega_{\xi}=\dot{\psi} \cdot \cos (\theta+\alpha)+\dot{\beta}+\dot{\theta} \cdot \gamma_{a} \\
q=\Omega_{\eta}=\dot{\psi} \cdot \sin \theta \cdot \beta-\dot{\psi} \cdot \cos \theta \cdot \gamma_{a}+\dot{\theta}+\dot{\alpha} \\
r=\Omega_{\zeta}=\dot{\psi} \cdot \sin (\theta+\alpha)+\dot{\varphi}-\dot{\theta} \cdot \beta+\dot{\beta} \cdot \alpha .
\end{gathered}
$$

Substituting (10) into the expression for the kinetic energy of the projectile (8) and calculating the derivatives of the kinetic energy of the projectile according to the corresponding generalized coordinates and velocities in the Lagrange equations (7), we obtain differential equations of the rotational motion of the projectile in the tubular guide for the angles of attack $\alpha$ and slip $\beta$ which are given below together with the equations of motion of the center of mass. The differential equations for the velocity angles $\Psi$ and $\theta$ are obtained by writing the equations of motion of the center of mass on the axis of the trajectory coordinate system. The aerodynamic angle of heel ya of the transition from the trajectory 
coordinate system to the velocity coordinate system is determined from kinematic considerations. For this, we consider the transition matrices from the starting to the trajectory coordinate system, from the trajectory to the velocity coordinate system, and from the velocity to the semi-linked coordinate system, as well as the matrix of the direct transition from the starting to the semi-linked coordinate system. Multiplying successively the first three matrices and equating the corresponding elements of the obtained matrix and the direct transition matrix, we will get:

$$
\sin \gamma_{a}=\frac{\sin \beta \cdot \sin \theta}{\cos \beta \cdot \cos \theta}=\operatorname{tg} \beta \cdot \operatorname{tg} \theta
$$

The time derivative of the aerodynamic angle of heel $\dot{\gamma}_{\mathrm{a}}$, which is included in the equations of rotational motion of the projectile, is found by differentiating in time (11):

$$
\dot{\gamma}_{a}=1 / \cos \gamma_{a} \cdot\left[\operatorname{tg} \theta / \cos ^{2} \beta \cdot \dot{\beta}+\operatorname{tg} \beta / \cos ^{2} \theta \cdot \dot{\theta}\right]
$$

The angle of rotation of the projectile $\varphi$, the speed $\dot{\varphi}$ and the acceleration $\ddot{\varphi}$ of its rotation are easily found from kinematic considerations and are determined by the angle of inclination of the screw groove. The yaw angle $\Psi_{\Pi}$ and the pitch angle $\theta \Pi$ of the velocity vector of the center of mass of the projectile in the launch coordinate system are determined by integrating the equations of motion of the center of mass into the projections on the axis of this coordinate system. The yaw angle $\Psi$ and the pitch angle $\theta$ of the velocity vector of the center of mass of the projectile in the starting coordinate system are determined by integrating the equations of motion of the center of mass into the projections on the axis of the trajectory coordinate system.

The yaw $\psi_{n}$ and pitch $U_{n}$ angles which determine the position of the projectile axis in the launch coordinate system $C^{\prime} x_{\Pi} y_{\Pi} z_{\Pi}$ are necessary for calculations by dependences (2), (3) of the pipe elastic reaction force, which are calculated by the angles $\Psi_{\Pi}, \theta_{\Pi}, \Psi, \theta, \alpha, \beta$. For this, the matrix of the guide cosines between the axes of the launch $C^{\prime} x_{\Pi} y_{\Pi} z_{\Pi}$ and the semi-connected $\mathrm{C} \zeta \xi \eta$ coordinate systems is determined by successive transitions from the launch to the trajectory system by turns at the angles $\Psi_{n}$ and $\theta_{\Pi}$, from the trajectory to the velocity coordinate system by rotation at the angle $Y_{a}$, from the velocity to the semi-connected system 
by turns at the angles $\beta$ and $\alpha$ and its elements are equated to the elements of the matrix of the direct transition from the launcher to the semi-connected system by turns at the angles $\psi_{\Pi}$ and $u_{\Pi}$.
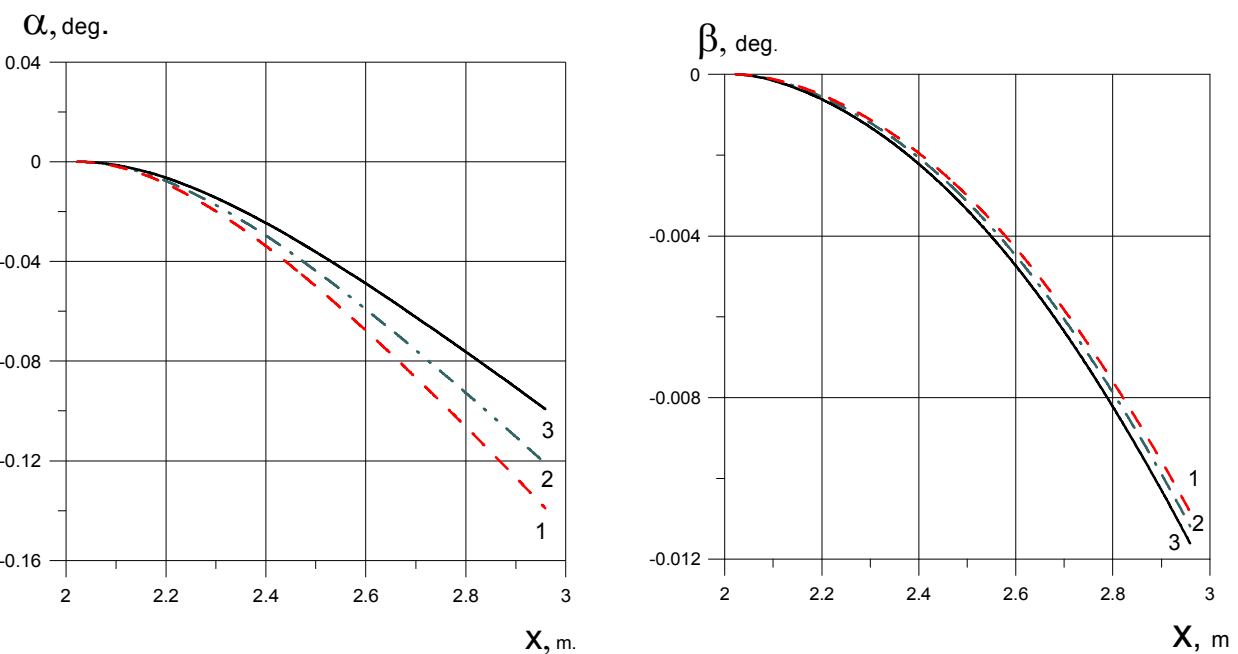

Figure $10-$ Calculated values of the angle of attack $\alpha$ and the angle of slip $\beta$ of the projectile along the length of the section $x$ of spatial motion at different elevation angles $\theta_{0}$ of the tubular guide: $1-\theta_{0}=19^{\circ} 4^{\prime} ; 2-\theta_{0}=33^{\circ} 36^{\prime} ; 3-\theta_{0}=45^{\circ} 46^{\prime}$.

Pис. 10 - Расчетные значения угла атаки $\alpha$ и угла скольжения $\beta$ снаряда по длине участка х пространственного движения при различных углах $\theta_{0}$ возвышения трубчатой направляющей: $1-\theta_{0}=19^{\circ} 4^{\prime} ; 2-\theta_{0}=33^{\circ} 36^{\prime} ; 3-\theta_{0}=45^{\circ} 46^{\prime}$.

Слика 10 - Израчунате вредности нападног угла $\alpha$ и угла клизања $\beta$ пројектила дуж дужине пресека х просторног кретања на различитим угловима елевације $\theta_{0}$ лансирне цеви: $1-\theta_{0}=19^{\circ} 4^{\prime} ; 2-\theta_{0}=33^{0} 36^{\prime} ; 3-\theta_{0}=45^{\circ} 46^{\prime}$.

If the generalized coordinate is the rotation angle, then the generalized force in equation (7) is the projection of the acting moment onto the axis of the elementary rotation. In this case:

$$
Q_{\alpha}=M_{\alpha}=M_{\eta}, \quad Q_{\beta}=M_{\beta}=M_{y_{a}}
$$

where $\mathrm{M}_{\alpha}$ is the moment of forces acting on the projectile relative to the axis of rotation by an angle $\alpha$ (axis $\eta$ in Fig. 2), and $M_{\beta}$ is the moment of acting forces relative to the axis of rotation by an angle $\beta$ (axis $y_{a}$ in Fig.2). 
By writing the equations of motion of the center of mass of the projectile in the projections on the axis of the launch $C^{\prime} x_{\Pi} y_{\Pi} z_{\Pi}$ and trajectory CTNB coordinate systems and adding to them the equations of rotational motion of the projectile relative to the center of mass in the form (7), we obtain the following system of equations which corresponds to the spatial motion of the projectile in the tubular guide:

1). $\ddot{x}_{n}=\frac{1}{m} \cdot\left[P(t)-\left(m g \cdot \cos \Theta_{0}-N_{y}(t)\right) \cdot f-\right.$

$$
\left.-m g \cdot \sin \Theta_{0}+N_{x}(t)+R_{\Sigma x}\right]
$$

2). $\ddot{y}_{n}=\frac{1}{m} \cdot\left[-m g \cdot \cos \Theta_{0}+N_{y}(t)+R_{\Sigma y}\right]$;

3). $\ddot{z}_{n}=\frac{1}{m} \cdot\left(N_{z}(t)+R_{\Sigma z}\right)$;

4). $\dot{V}=\Sigma F_{T} / m$;

5). $\dot{\theta}=\Sigma F_{N} /(m \cdot V)$;

$6) . \dot{\psi}=-\Sigma F_{B} /(m \cdot V \cdot \cos \theta)$;

7). $B \cdot \ddot{\alpha}+(A-C) \cdot\left[\dot{\Psi}^{2} \cdot \sin (\theta+\alpha) \cdot \cos (\theta+\alpha)+\right.$

$$
+\dot{\Psi} \cdot \dot{\beta} \cdot \sin (\theta+\alpha)]-H \cdot[\dot{\Psi} \cdot \cos (\theta+\alpha)+\dot{\beta}]=M_{\eta} ;
$$

8). $A \cdot \ddot{\beta}+A \cdot\left[-\dot{\Psi} \cdot \dot{\theta} \cdot \sin (\theta+\alpha)+\dot{\theta} \cdot \dot{\gamma}_{a}\right]-$

$$
-B \cdot\left[\dot{\Psi}^{2} \cdot \sin \beta \cdot \cos \beta+\dot{\Psi} \cdot \cos \beta \cdot(\dot{\theta}+\dot{\alpha})\right]+
$$

$+C \cdot[\dot{\Psi} \cdot \dot{\alpha} \cdot \sin (\theta+\alpha)+\dot{\Psi} \cdot \dot{\theta} \cdot \sin \theta+$

$\left.+\dot{\varphi} \cdot(\dot{\theta}+\dot{\alpha})+\ddot{\varphi} \cdot \alpha-\dot{\theta}^{2} \cdot \beta\right]=M_{y_{a}}$

The total vector of moments acting on the projectile forces relative to its center of mass is written as follows:

$$
\vec{M}_{c}=\overrightarrow{C A} \times \vec{R}_{\sum}+\overrightarrow{C K} \times \vec{N}_{\sum}
$$

where $\vec{R}_{\Sigma}=\vec{R}+\vec{F}_{T}+\vec{F}_{T 1}$ represents the vector sum of the forces applied at the reference point "A", and $\vec{N}_{\Sigma}=\vec{N}(t)+\vec{F}_{\text {Tा }}$ is the vector sum of the forces applied to the projectile pin at the point "K" (Fig. 2). The 
projections of this vector on the direction of the $\eta$ and $y_{a}$ axes give the moment values $M_{\eta}$ and $M_{y_{a}}$.
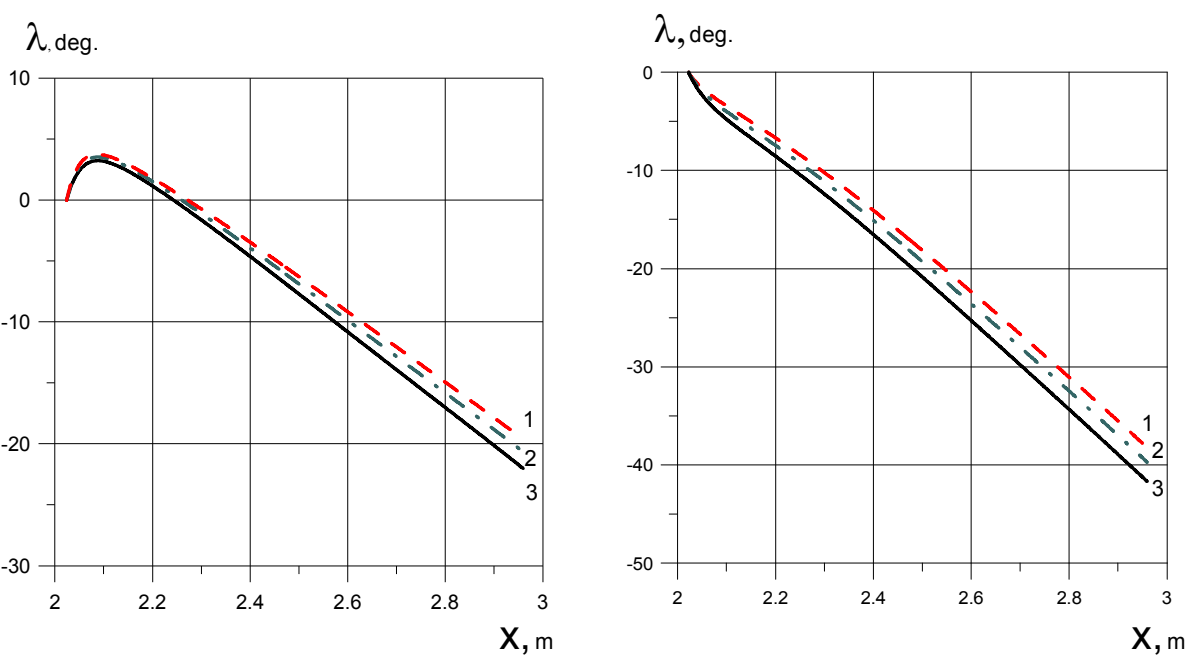

Figure $11-$ Calculated values of the angle $\lambda$ of the contact of the projectile with the guide (Fig. 5) along the length of the section $x$ spatial movement with a slope angle of of the screw $2.5^{\circ}$ and the initial angular coordinate of the screw groove $\varphi_{\pi 0}=15^{\circ}$ (left) and $\varphi_{\pi 0}=$ $30^{\circ}$ (right): $1-\theta_{0}=19^{\circ} 4^{\prime} ; 2-\theta_{0}=33^{\circ} 36$ '; $3-\theta_{0}=45^{\circ} 46^{\prime}$.

Puc. 11 - Расчетные значения угла $\lambda$ контакта снаряда с направляющей (рис.5) по длине участка х пространственного движения с углом наклона $2.5^{\circ} \mathrm{u}$ начальной угловой координатой винтового паза $\varphi_{\text {по }}=15^{\circ}$ (слева) и $\varphi_{\text {по }}=30^{\circ}$ (справа): $1-\theta_{0}=19^{\circ} 4^{\prime} ; 2-\theta_{0}=33^{\circ} 36^{\prime} ; 3-\theta_{0}=45^{\circ} 46^{\prime}$.

Слика 11 - Израчунате вредности угла $\lambda$ контакта пројектила са водиштем (сл. 5) дуж дужине пресека х просторног кретања са углом нагиба $2,5^{\circ}$ и почетном угаоном координатом спиралног вијка $\varphi_{\text {по }}=15^{\circ}$ (лево) и $\varphi_{\text {по }}=30^{\circ}$ (десно): $1-\theta_{0}=$ $19^{\circ} 4^{\prime} ; 2-\theta_{0}=33^{0} 36^{\prime} ; 3-\theta_{0}=45^{\circ} 46^{\prime}$.

As a result of the numerical solution of the system of differential equations (14), we find the values of the velocity of the center of mass of the projectile $V$, the angles $\Psi$ and $\theta$, which determine the direction of the velocity vector of the center of mass in the starting coordinate system, the angles $\alpha$ and $\beta$, which determine the direction of the axis of the projectile with respect to the velocity vector, as well as the numerical values of the components of the angular velocity of the projectile $\overrightarrow{\dot{\Psi}}, \overrightarrow{\dot{\theta}}, \overrightarrow{\dot{\alpha}}, \overrightarrow{\dot{\beta}}$ (Fig. 2). Since the spatial orientation of the projectile axis in the starting coordinate system is determined by the angles $\psi$ and $\cup$ (Fig. 2) when calculating the parameters of the projectile trajectory, then, by 
converting the coordinates, the obtained angles are recalculated by $\psi$ and $u$.

The instantaneous angular velocity of the projectile is determined by dependence (7). On the other hand, this angular velocity

$$
\vec{\Omega}=\overrightarrow{\dot{\psi}}+\overrightarrow{\dot{v}}+\overrightarrow{\dot{\varphi}}
$$

Equating the right-hand sides of (7) and (14), we will obtain

$$
\overrightarrow{\dot{\psi}}+\overrightarrow{\dot{v}}=\overrightarrow{\dot{\psi}}+\overrightarrow{\dot{\theta}}+\overrightarrow{\dot{\alpha}}+\overrightarrow{\dot{\beta}}
$$

By writing, using the transition tables, (17) in the projections on the axis of the rotation angles $\psi$ and $u$, which are the $y$ ' and $\eta$ axes, (Fig. 2), we obtain, respectively:

$$
\dot{\psi}=\dot{\Psi}+\dot{\beta} \cdot \cos \gamma_{a} \cdot \cos \Theta ; \quad \dot{v}=\dot{\Theta} \cdot \cos \gamma_{a} \cdot \cos \beta+\dot{\alpha}
$$

In Figs. 9 - 11, the results of the calculations of the movement of an M-21OF missile inside the tube guide of a BM-21 mobile launcher are presented. In Fig. 8, the left side shows the calculated values of the reaction force of the screw groove $N$ and its projections $N_{x}, N_{y}$, and $N_{z}$ on the axis of the launch coordinate system $C^{\prime} x_{\Pi} y_{\Pi} z_{\Pi}$ along the length of the spatial motion of the projectile at an elevation angle of the tubular guide $\theta_{0}=33^{0} 36^{\prime}$. The calculated values of the angle $\lambda$ of the contact of the projectile with the guide according to Fig. 5 are given in Fig. 11. The content of the remaining figures can be seen from the figure captions.

\section{Conclusions}

1) A computational and mathematical model of the spatial motion of a rocket with centering thickenings and a leading pin on the housing in an elastic thin-walled tubular guide provided with a screw groove on the fixed supports is developed, taking into account the interaction of the projectile with the inner surface of the guide tube at the locations of the leading pin and centering thickenings of the projectile.

2) The force of the normal reaction of the inner surface of the guide acting on the projectile is found as a reaction to the elastic deformation of the pipe caused by normal center-of-center displacements of the tube in contact with the guide. In this case, the tubular guide is considered as an 
elastic thin-walled shell. To calculate the values of the shell stiffness coefficient along its length, the finite element method implemented in the ANSYS Mechanical software package was used.

3) The generalized parameters of the rotational motion of the projectile are the yaw velocity angles $\psi$ and pitch $\theta$, the angle of attack $\alpha$ and the slip angle $\beta$, as well as the rotation angle around the longitudinal axis $\varphi$. The time derivatives of the yaw velocity angles $\Psi$ and pitch $\theta$ are determined by writing a theorem on the motion of the center of mass of the projectile on the axis of the trajectory coordinate system CTNB and are taken as components of the angular velocity of the projectile. the generalized calculated parameters of the rotational motion are the angle of attack $\alpha$ and the slip angle $\beta$, as well as the rotation angle around the longitudinal axis $\varphi$. The aerodynamic angle of heel $\gamma_{a}$ is found from the transition formulas for the adopted coordinate systems. The yaw velocity angles $\Psi$, pitch $\theta$, the aerodynamic roll angle $\gamma_{a}$, the angle of attack a and the slip angle $\beta$ as well as the first time derivatives of these angles are converted into the yaw angles $\psi$ and pitch $u$ of the projectile axis and their derivatives in the starting coordinate system.

4) The results of the calculations of the above angles, as well as the forces on the pin and at the point of contact of the projectile with the guide, are presented.

\section{References}

Antunevich, A.L., Il'jov, I.G., Goncharenko, V.P. \& Mironov, D.N. 2017. Application of mathematical models for the analysis of complex mechanical system undergoing heterogeneous variable actions. Theoretical and applied mechanics, 32, pp.207-213 (in Russian). (In the original: Антуневич, А.Л., Ильёв, И.Г., Гончаренко, В.П., Миронов Д.Н. 2017. Применение математической модели для анализа сложной механической системы, подверженной неоднородным переменным воздействиям. Теоретическая и прикладная механика, 32, стр.207-213). Available at: http://rep.bntu.by/handle/data/28261 [Accessed: 30 July 2019].

Bogomolov, A.I. 2003. Osnovanija ustrojstva i raschet reaktivnyh system. Penza: Penza Artillery Engineering Institute (in Russian). (In the original: Богомолов, А.И. 2003. Основания устройства и расчет реактивных систем. Пенза: Пензенский артиллерийский инженерный институт).

Dziopa, Z., Buda, P., Nyckowski, M., \& Pawlikowski, R. 2015. Dynamics of an unguided missiles launcher. Journal of theoretical and applied mechanics, 53(1), pp.69-80. Available at: https://doi.org/10.15632/jtam-pl.53.1.69. 
Dziopa, Z., Krzysztofik, I., \& Koruba, Z. 2010. An analysis of the dynamics of a launcher-missile system on a moveable base. Bulletin of the Polish Academy of Sciences. Technical Sciences, 58(4), pp.645-650. Available at: https://doi.org/10.2478/v10175-010-0068-5.

Raducanu, D., Nedelcu, I., Safta, D., Somoiag, P., \& Moldoveanu, C. 2009. Particularity Concerning Evaluation of Unguided Rocket Trajectories Deviation under the Disturbance Factors Action. In: Proceedings of the World Congress on Engineering 2009, London, Vol II WCE, pp.1458-1462, July 1-3. Available at: http://www.iaeng.org/publication/WCE2009/WCE2009_pp1458-1462.pdf

[Accessed: 30 July 2019].

Shyiko, O.M. 2014. Simulation of joint movement of a missile and a mobile launcher. Armament systems and military equipment, 2(38), pp.44-60. (in Ukrainian). (In the original: Шийко О.М. 2014. Моделювання сумісного руху реактивного снаряда та мобільної пускової установки РСЗВ. Системи озброєння і військова техніка, 38(2), стр.44-60).

Somoiag, P., Moraru, F., Safta, D., \& Moldoveanu, C. 2007. A Mathematical Model for the Motion of a Rocket-Launching Device System on a Heavy Vehicle. WSEAS Transactions on Applied and Theoretical Mechanics, 2(4), pp.95-101. Available at: https://www.researchgate.net/publication/261708644 [Accessed: 30 July 2019].

Svetlickij, V.A. 1986. Dinamika starta letatelnyh apparatov. Moscow: Nauka. Gl. red. fiz.-mat. lit. (in Russian). (In the original: Светлицкий, В.A. 1986. Динамика старта летательных аппаратов. Москва: Наука. Гл. ред. физ.мат.лит.).

МОДЕЛИРОВАНИЕ ДВИЖЕНИЯ РЕАКТИВНОГО СНАРЯДА В ТРУБЧАТОЙ НАПРАВЛЯЮЩЕЙ ПУСКОВОЙ УСТАНОВКИ

Александр Н. Шийко, корреспондент ${ }^{\text {, }, ~ А н а т о л и и ̆ ~ М . ~ П а в л ю ч е н к о ~}{ }^{\text {, }}$ Алексей А. Обухов ${ }^{6}$, Игорь В. Коплык ${ }^{\mathrm{B}}$

а Национальный аграрный университет, Сумы, Украина

${ }^{б}$ Научно-исследовательский центр ракетных войск и артиллерии, Сумы, Украина

${ }^{\text {в } Г о с у д а р с т в е н н ы и ̆ ~ у н и в е р с и т е т, ~ С у м ы, ~ У к р а и н а ~}$

РУБРИКА ГРНТИ: 78.25.16 Вооружение и техника ракетных войск; 78.25.17 Вооружение и техника войск ПВО

ВИД СТАТЬИ: оригинальная научная статья ЯЗЫК СТАТЬИ: английский

Резюме:

В данной статье представлены расчетная и математическая модели пространственного движения реактивного снаряда с центрирующими утолщениями и ведущим штифтом на корпусе в тонкостенной трубчатой направляющей, закрепленной на двух неподвижных опорах и снабженной винтовым пазом. Модели учитывают взаимодействие снаряда с внутренней поверхностью 
трубы направляющей в местах размещения ведущего штифтта и центрирующиего утолщения. Сила нормальной реакции внутренней поверхности направляющей находится как реакция на упругую дефрормацию трубы, вызванная нормальными $\kappa$ eе внутренней поверхности перемещениями центрирующего утолщения в месте контакта с направляющей. При этом трубчатая направляющая рассматривается как упругая тонкостенная оболочка. Для расчета значений коэфрфициента жесткости оболочки по ее длине используется метод конечных элементов, реализованный в пакете программ ANSYS Mechanical. Поступательная составляющая движения снаряда исследуется на основании теоремы о движении центра масс. Вращательная составляющая исследуется на основании уравнений Лагранжа 2-го рода. Обобщенными параметрами вращательного движения являются скоростные углы рыскания $\psi$ и тангажа $\theta$, угол атаки $\alpha$, угол скольжения $\beta$, угол поворота снаряда вокруг продольной оси $\varphi$. Аэродинамический угол крена уа находится из формул перехода для принятых систем координат. Скоростные углы рыскания $\boldsymbol{\psi}$, тангажа $\theta$, аэродинамический угол крена $\gamma_{a}$ и первые производные по времени этих углов пересчитываются в углы рыскания $\psi$ и тангажа и оси снаряда и их производные в стартовой системе координат. Приведены результаты расчетов некоторых указанных выше углов, а также сил на штиярте и в точке контакта снаряда с направляющей.

Ключевые слова: реактивный снаряд, пусковая установка, упругая модель, трубчатая направляющая, пространственный участок движения, сила взаимодействия, уәлы вектора, скорости центра масс, углы оси снаряда.

\section{МОДЕЛИРАЊЕ КРЕТАЊА ПРОЈЕКТИЛА У ЛАНСИРНОЈ ЦЕВИ}

Александар Н. Шијко, аутор за преписку ${ }^{a}$, Анатолиј М. Пављученко ${ }^{\text {, }}$ Алексеј А. Обухов ${ }^{6}$, Игор В. Коплик

${ }^{\text {а }}$ Национални пољопривредни универзитет, Суми, Украјина

${ }^{\sigma}$ Научноистраживачки центар артиљеријско-ракетних јединица,

Суми, Украјина

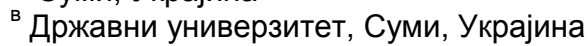

ОБЛАСТ: механика, артиљеријско-ракетно наоружање

ВРСТА ЧЛАНКА: оригинални научни рад

ЈЕЗИК ЧЛАНКА: енглески

\section{Сажетак:}

У овом раду су представљени прорачунски и математички модели просторног кретања пројектила са центрирајућим прстеном и водећим прстеном на телу у танкозидној лансирној цеви, која је 
фриксирана за два стабилна носача и опремљена спиралним вијком. Приликом моделовања узима се у обзир интеракција пројектила са унутрашњом површином лансирне цеви у местима контакта центрирајућег прстена са водиштем цеви. Сила нормалне реакције унутрашње површине лансирне цеви се израчунава као реакција на еластичну деформацију цеви која је изазвана уобичајеним померањем центрирајућег прстена у месту контакта са водиштем лансирне цеви. У овом случају водиште лансирне цеви се разматра као еластична танкозида чаура. У циљу прорачуна вредности коефицијента крутости чауре, користи се метода коначних елемената, имплементирана у софртверском пакету ANSYS Mechanical. Транслациона компонента кретања пројектила истражује се на основу теореме средишта кретања масе, а ротациона компонента на основу Лагрангеових једначина друге врсте. Генерализовани параметри ротационог кретања су углови окретања брзине $\psi$ и висине $\theta$, угао напада $\alpha$, угао клизања $\beta$ и угао ротације пројектила око уздужне осе $\varphi$. Аеродинамички угао нагиба $\gamma_{a}$ се израчунава из прелазних формула за усвојене координатне системе. Угао скретања брзине $\psi$, висине $\theta$, аеродинамички угао нагиба $\gamma_{а}$ и први деривати ових углова претварају се у углове скретања $\psi$ и висине и осе пројектила и њихове деривате у почетном координатном систему. У раду су такође приказани резултати прорачуна неких од наведених углова, као и утицај силе на центрирујући прстен у месту контакта пројектила са водиштем лансирне цеви.

Кључне речи: ракетни пројектил, покретни лансер, еластични модел, лансирна цев, просторни пресек кретања, силе интеракције, углови вектора, брзине центра масе, углови осовине пројектила.

Дата получения статьи / Paper received on / Датум пријема чланка: 30.07.2019. Дата получения откорректированной версии статьи / Manuscript corrections submitted on / Датум достављања исправки рукописа: 29.09.2019.

Дата окончательного согласования статьи / Paper accepted for publishing on / Датум коначног прихватања чланка за објављивање: 30.09 .2019 .

(C) 2019 The Authors. Published by Vojnotehnički glasnik / Military Technical Courier (www.vtg.mod.gov.rs, втг.мо.упр.срб). This article is an open access article distributed under the terms and conditions of the Creative Commons Attribution license (http://creativecommons.org/licenses/by/3.0/rs/).

() 2019 Авторы. Опубликовано в «Военно-технический вестник / Vojnotehnički glasnik / Military Technical Courier» (www.vtg.mod.gov.rs, втг.мо.упр.срб). Данная статья в открытом доступе и распространяется в соответствии с лицензией «Creative Commons» (http://creativecommons.org/licenses/by/3.0/rs/).

(c) 2019 Аутори. Објавио Војнотехнички гласник / Vojnotehnički glasnik / Military Technical Courier (www.vtg.mod.gov.rs, втг.мо.упр.срб). Ово је чланак отвореног приступа и дистрибуира се у складу са Creative Commons licencom (http://creativecommons.org/licenses/by/3.0/rs/). 